\title{
Susceptibility of some Rose Varieties to Verticillium Wilt and Role of Beat Moss and Compost on its Control
}

Hanaa A. H. Armanious

Plant Pathol. Dept., Fac. Agric., Minia Univ., Egypt.

\begin{abstract}
Qix rose species or varieties, i.e. Rosa gallica var Aegyptiaca, Rosa Sybrid var. Hamoschush, Rosa. Hybrid var. Queen, Rosa hybrid var. Yellow, Rosa hybrid var. White and Rosa canina were tested to study their relative susceptibility to infection by Verticillium dahliae, the causal pathogen of rose wilt. All tested varieties and species of rose are liable to infection with different degrees. Isolates $\mathrm{VD}_{1}$ and $\mathrm{VD}_{2}$ appeared to be the most pathogenic ones.Rosa canina was the highly resistant to Verticillium wilt. Rosa gallica var. Aegyptiaca, $R$. hybrid var. Yellow, R. hybrid var. White and $R$. hybrida var. Queen are the most susceptible, while Rosa hybrida var. Hamoschush was moderately susceptible to any of the tested isolates. Mixing the Nile loamy soil with different levels of peat moss led to remarkable decrease of both disease incidence (DI, \%) and severity (DS, \%). The percentages of reduction of DI and DS were increased with increasing the rate of peat moss amended to soil. The maximum infection with any of the tested isolates occurred in the raw loamy soil, 90 days after sowing, whereas the lowest infection resulted when soil was mixed with peat moss by $66.6 \%$ (1:2 ratio). Amending of either Bio-Pianta compost or rice straw compost to the soil before sowing significantly decreased the wilt of rose incidence by $44.4-88.9$ and disease severity by 45.7 - $91.6 \%$ when compared with the control (compost free soil), in both seasons of the experiment. The Bio-Pianta compost caused higher reduction in both DI, \% and DS, \% of rose wilt if compared with rice straw.
\end{abstract}

Keywords:Compost, disease control, peat moss, rose, varieties,Verticillium wilt.

Roses are known as a garden staple, producing delicate blooms in vibrant colors that fill the air with anenjoyable fragrance. Roses grow in different types including miniature, climbing and shrub. Several fungal diseases can attack many species and cultivars of roses which are not immune to infection. Verticillium dahliae Kleb is one of the danger micro- pathogens that attack rose seedlings and adult plants causing severe damage (Hammett, 1971 and Horst, 1983). This fungus lives a long time in the soil as saprophytic mycelium, conidiospores and microsclerotia, infecting a broad range of hosts. Rose rootstocks differ in their susceptibility to infection with Verticilliumspp., e.g. Rosa orodata and "Ragged Robin cv." are susceptible; "Dr. Huey cv." and $R$. multiflora have more resistance, whereas Rosa chinensis var. manetti is very resistant to infection with $V$. dahaliae (Horst, 1983).In Japan, Li et al. (2007) reported that the use of resistant rootstock of Rosa multiflora 
(Matsushima No. 3 cultivar) is a valuable strategy toward legal restrictions and consumer concerns against fungicide application for controlling Pythium helicoides root rot.

Mixing peat moss with soil gets a good aeration and moist soil for longer time, it is used as soil conditioner because it can hold lots of water and does not decay easy. Aly et al. (2002)used a mixture of peat moss, sand and clay $(1: 1: 1 \mathrm{w} / \mathrm{w} / \mathrm{w})$ as a soil infested with Botriodiplodia theobromae to study the incidence of grapevine twigs tip die-back disease. In 2008, Pacholczak and Szydlo found that ninebacrk (Physocarpus opulifolius)stem cuttings gave the best rooting and growth when cultivated in a mixture of White peat and perlite $(2: 1)$.

Composting has been defined as "the biological decomposition of organic constituents in wastes under controlled conditions (Golueke, 1972).Organic wastes, primarily by-products of many industrial activities, include crop residues, animal manures and municipal biosolids. To reduce the environmental strain, it is essential to make organic wastes a resource rather than a by-product. Possible utilization of organic wastes includes uses as a fertilizer and soil amendments. Naturally, farmers have used animal manures and residues of some crops as a fertilizer to improve soil physical and chemical properties.

The use of compost as a peat substance to control soil borne pathogens was first suggested by Hoitink et al. (1975). Since then, several soil-borne plant pathogens have been reduced (Hoitink and Fahy, 1986; Cotxarrera et al., 2002; Borrero et al., 2004 and Litterick et al., 2004).

Larkin (2008) reported that aerated compost tea (ACT) and its combination with a mixture of beneficial microorganisms reduced stem canker, black scurf and common scab of potatoes' tubers by $18-33 \%$, and increased the yield by $20-23 \%$.

The present investigation was conducted to study susceptibility of some rose species and varieties to the most pathogenic isolates of Verticillium dahliaeand to studythe effect of soil amended with peat moss or compost in controlling rose wilt.

\section{Materials and Methods}

\section{Source of the pathogen:}

These experiments were conducted in a trial to find out the most unfavorable conditions for development of the Verticilliumwilt of rose. Three pathogenic isolates of Verticillium dahliae (designated as $\mathrm{VD}_{1}, \mathrm{VD}_{2}$ and $\mathrm{VD}_{8}$ ) were isolated from wilted rose plants collected from Minia Governorate, purified and identified in Plant Pathology Department, Faculty of Agriculture, Minia University (Armanious, 2016) and were used in this study. Pot experiments were carried out in the open experimental field of Plant Pathology Department, Faculty of Agriculture, Minia University, during winter-spring seasons of 2014 and 2015. In this study, sterilization of pots $(30 \mathrm{~cm}$ in diameter), soil dis-infestation, surface sterilization ofrose cuttings, preparation of inocula, and soil infestation with the desired 
inoculum, time of soil infestation ( 7 days before planting), and replications ( 4 pots each containing 3 cuttings of rose ( $R$. gallica var. Aegyptiaca) were applied as described by Armanious (2016).

In all experiments, Nile loamy soil was used. The pots were irrigated every 5 days (75\% of field capacity). The average percentagesof wiltincidence (DI, \%) and Disease severity (DS, \%) of each treatment were calculated, 90 daysafter cutting planting.

Disease severity on the aboveground plant parts was evaluated using a modified scale of Bejarano-Alcázar et al. (1996) based on the percentage of foliage appeared chlorosis, necrosis, wilting, defoliation, and the presence of discoloration in vascular tissue in the stem as follows:

$0=$ no symptoms;

$1=1$ to $33 \%$ foliage affected;

$2=1$ to $33 \%$ foliage affected with vascular discoloration;

$3=34$ to $66 \%$ foliage affected;

$4=34$ to $66 \%$ foliage affected with vascular discoloration;

$5=67$ to $100 \%$ foliage affected;

$6=67$ to $100 \%$ foliage affected with vascular discoloration and

$7=$ dead plant. Each plant showing symptoms at the crown was cut longitudinally to assess the presence of vascular discoloration.

The percentage of disease severity (DS, \%) was calculated according to the following formula:

$$
\mathrm{D} \%=\frac{1 \mathrm{xN}_{1}+2 \mathrm{xN}_{2}+3 \mathrm{xN}_{3}+\ldots \ldots .7 \mathrm{xN}_{7}}{7 \times \mathrm{N}} \times 100
$$

Where,

$\mathrm{N}_{1}, \mathrm{~N}_{2}, \mathrm{~N}_{3}, \ldots \mathrm{N}_{7}$ are numerical values of the grade as in the mentioned scale (7) is the maximum number of scale grade and $\mathrm{N}$ is the total number of plants.

2. Susceptibility of different species or varieties of rose to wilt pathogen:

Six species or varieties of rose, i.e. Rosa gallica var. Aegyptiaca, Rosa hybrid var. Hamoschush, Rosa. Hybrid var. Queen, Rosa hybrid var. Yellow, Rosa hybrid var. White and Rosa canina were tested to study their relative susceptibility to infection with rose wilt.

3. Effect of peat moss amended to soil on Verticillium of rose wilt:

In this experiment, four levels of peat moss were added to autoclaved Nile loamy soil; raw Nile loam and its mixture with peat-moss at ratios of 2:1 and 1:1 and $1: 2, \mathrm{v} / \mathrm{v})$ to test their effect on rose infection with the Verticillium wilt. 
4. Effect of compost on controlling rose wilt:

To study the effect of composted agricultural residues of the farm on controlling wilt of rose under greenhouse condition, a rice straw based and Bio-Pianta composts (Table 1)were amended to Nile loamy soil. Rice straw based compost was kindly provided by Prof. Dr. El-Banna, A., prepared in the Laboratory of preparing compost, Plant Pathology Department, Faculty of Agriculture, Minia University and Bio-Pianta compost was prepared and obtained from Al-Menofia Fertilizers andChemical Company. Surface sterilized cuttings of rose ( $R$. gallica var. Aegyptiaca) were planted in sterilized pots filled with Nile-loamy soil amended with compost $(4: 1 \mathrm{w} / \mathrm{w})$. Two weeks before sowing, compost was added to the sterilized soil, mixed thoroughly and irrigated (Raj and Kapoor, 1997). Compost free soil and non-infested soil were used as control treatment. Four pots were used as replicates, each pot containing three cuttings. The percent of wilted roseplants and disease severity were calculated, 90 days after sowing.

Table 1. Characteristics of compost used in the present study

\begin{tabular}{|c|c|c|c|c|c|c|c|c|c|}
\hline $\begin{array}{c}\text { The } \\
\text { sourc } \\
\mathrm{e}\end{array}$ & $\begin{array}{c}\mathrm{Wt} \\
(\mathrm{kg}) / \mathrm{m}\end{array}$ & $\begin{array}{c}\text { Moistur } \\
\mathrm{e}\end{array}$ & $\begin{array}{c}\mathrm{p} \\
\mathrm{H}\end{array}$ & $\begin{array}{c}\mathrm{E} \\
\mathrm{C}\end{array}$ & $\begin{array}{c}\text { Organi } \\
\mathrm{c} \\
\text { matter }\end{array}$ & $\begin{array}{c}\text { TotalN }(\% \\
)\end{array}$ & $\begin{array}{c}\mathrm{C} / \mathrm{N} \\
\text { rati } \\
\mathrm{o}\end{array}$ & $\begin{array}{c}\text { Availabl } \\
\mathrm{e} \\
\mathrm{P} \mathrm{mg} / \mathrm{kg}\end{array}$ & $\begin{array}{c}\text { Total } \\
\mathrm{K}^{+}(\% \\
)\end{array}$ \\
\hline \hline $\begin{array}{c}\text { Bio- } \\
\text { Pianta }\end{array}$ & $\begin{array}{c}540- \\
600\end{array}$ & $15-20$ & $\begin{array}{c}7- \\
8\end{array}$ & $\begin{array}{c}3- \\
4\end{array}$ & - & $1-1.4$ & $\begin{array}{c}12- \\
20: 1\end{array}$ & $\begin{array}{c}0.26- \\
0.35\end{array}$ & $0.8-1$ \\
\hline \hline Straw & 600 & $20-26$ & $\begin{array}{c}7 . \\
5\end{array}$ & 2.6 & 38 & 1.9 & 13.1 & 1.9 & 0.9 \\
\hline
\end{tabular}

5. Statistical analysis:

Data of all experiments were analyzed by analysis of variance (ANOVA) using the General Linear Models procedure of Co. Stat. Significance between means was tested by "F" test and the value of LSD ( $p=0.05)$ was calculated (Snedecor and Cochran, 1982).

\section{Results and Discussion}

\section{Susceptibility of different varieties of rose to wilt pathogen:}

Six species or varieties of rose, i.e. Rosa gallica var. Aegyptiaca, Rosa hybrid var. Hamoschush, Rosahybrida var. Queen, Rosa hybrid var. Yellow, Rosa hybrid var. White and Rosa canina were tested to study their relative susceptibility to three virulent isolates of Verticillium dahliae, the causal pathogen of rose wilt (Table 2). All tested varieties and species of rose were infected by V.dahliae with different degrees. Data in Table (2) indicate that Rosa canina showed the highest degree of resistance to Verticillium wilt. Some varieties of rose, viz. Rosa gallica var. Aegyptiaca, R. hybrid var.Yellow, R. hybrid var. White and $R$. hybrida var. Queen were the most susceptible, while Rosa. Hybrid var. Hamoschush was moderately susceptible to any of the tested isolates. Also, isolates $\mathrm{VD}_{1}$ and $\mathrm{VD}_{2}$ were highly pathogenic followed by isolate $\mathrm{VD}_{8}$. During the second season, 2015, the same trend was obtained but the symptoms and degrees of infection, in some cases, were more

Egypt. J. Phytopathol., Vol. 44, No. 2(2016) 
severe than those in the first season. This may be due to the accumulation and increasing inoculum source in the same locations from year to year.

The majority of ornamental roses are hybrids that were bred for their flowers. Cultivars of rose are among the most popular landscape plants. Unfortunately, all the commonly grown rose varieties are susceptible to $V$. dahliae, although some are less susceptible than others but several breeding species or cultivars showed different degrees of resistance to Verticillium wilt of rose.

The use of resistant rootstocks against root rot disease is a valuable strategy toward legal restrictions and consumer concerns against fungicide application. So, the present study suggested grafting the susceptible rose varieties on $R$. canina, as a rootstock to increase their tolerant against VerticilliumwiltLi et al. (2007) foundthat the density of hyphae of Pythium helicoides in cortical cells of the resistant cultivar; Matsushima No.3 of Rosa multiflora, was less than that in the susceptible cultivar. Also, the hypha was inhibited before penetrating and expanding to cortical cells ofthe resistant cultivar.

2- Effect of soil amendment with peat moss on the incidence of rose wilt:

In order to study the effect of mixing peat moss with Nile loamy soil on the potency of the most pathogenic isolates of Verticillium dahliae, the rose wilt-inducing fungus, three levels, i.e. raw Nile loam; control, and its mixture with peat moss at ratios of 2:1, 1:1 and 0.5:1 w/w peat moss: soil) were used. Data of this experiment are presented in Tables (3 and 4). Date indicate that mixing soil with peat moss led to decrease both disease incidence (DI,\%) and severity (DS,\%). The percentages of reduction on DI and DS were increased with increasing the rate of peat moss in soil. It is clear that the maximum infection with any of the tested isolates $(91.7-100 \%$ for DI $\%$ and $45.3-62.0 \%$ for DS\%) was occurred in the raw loamy soil, 90 days after sowing. Mixing the raw Nile soil with peat moss by $66.6 \%$ (1:2 ratio) led to decrease values of disease incidence and disease severity. The percentages of DI were reduced to $33.3-41.7 \%$ and DS\% was decreased to $8.3 \%-14.3 \%$, at the $1^{\text {st }}$ growing season. These results are in agreement with those obtained by Pane et al. (2011) who found that peat amended with composts reduced damping-off caused by $R$. solani, Pythium ultimum and Sclerotium minor. Several methods pointed to control soil-borne fungi, included improving the sanitation procedures and agricultural practices. Mixing peat moss with soil led to moist soil for longer time, to get good aeration and it is also used as soil conditioner due to holding lots of water and decay slowly.

Egypt. J. Phytopathol., Vol. 44, No. 2(2016) 
Table 2. Susceptibility of six rose species or varieties to different isolates of Verticillium dahliae, inducing wilt, 90 days after sowing

\begin{tabular}{|c|c|c|c|c|c|}
\hline \multirow{2}{*}{$\begin{array}{l}\text { Verticillium } \\
\text { Isolates }\end{array}$} & \multirow{2}{*}{$\begin{array}{c}\text { Rose } \\
\text { variety or species }\end{array}$} & \multicolumn{2}{|c|}{2014 season } & \multicolumn{2}{|c|}{2015 season } \\
\hline & & DI,\% & DS, $\%$ & DI,\% & $\mathrm{DS}, \%$ \\
\hline \multirow[t]{6}{*}{$\mathrm{VD}_{1}$} & R. gallica var.Aegyptiaca & 83.3 & 62.0 & 83.3 & 64.4 \\
\hline & R. hybridavar.Queen & 83.3 & 36.9 & 75.0 & 38.1 \\
\hline & R. hybridavar.Yellow & 91.7 & 54.8 & 83.3 & 39.4 \\
\hline & R. hybridavar.White & 83.3 & 46.3 & 75.0 & 47.7 \\
\hline & R. hybridavar. Hamoschush & 41.7 & 16.7 & 50.0 & 25.0 \\
\hline & R. canina & 16.7 & 6.0 & 16.7 & 8.3 \\
\hline \multirow[t]{6}{*}{$\mathrm{VD}_{2}$} & R. gallica var. Aegyptiaca & 75.0 & 56.0 & 75.0 & 42.9 \\
\hline & R. hybridavar.Queen & 83.3 & 35.7 & 66.7 & 26.2 \\
\hline & R. hybridavar.Yellow & 75.0 & 23.8 & 66.7 & 31.0 \\
\hline & R. hybridavar. White & 66.7 & 22.0 & 66.7 & 32.2 \\
\hline & R. hybridavar. Hamoschush & 33.3 & 14.3 & 41.7 & 15.5 \\
\hline & R. canina & 8.3 & 2.4 & 33.3 & 10.7 \\
\hline \multirow[t]{6}{*}{$\mathrm{VD}_{8}$} & R. gallica var. Aegyptiaca & 75.0 & 45.3 & 75.0 & 36.9 \\
\hline & R. hybridavar.Queen & 58.3 & 22.6 & 50.0 & 23.8 \\
\hline & R. hybridavar.Yellow & 58.3 & 22.6 & 50.0 & 16.7 \\
\hline & R. hybridavar.White & 58.3 & 20.2 & 41.7 & 19.1 \\
\hline & R. hybridavar. Hamoschush & 16.7 & 8.3 & 25.0 & 11.9 \\
\hline & $R$. canina & 8.3 & 3.6 & 8.3 & 3.6 \\
\hline \multicolumn{2}{|l|}{ LSD 5\% for: } & 0.33 & 5.86 & 0.52 & 8.45 \\
\hline \multicolumn{2}{|l|}{ Varieties (B) } & 0.7 & 12.62 & 0.61 & 12.21 \\
\hline \multicolumn{2}{|l|}{ Interaction $(\mathrm{AxB})$} & 0.8 & 14.36 & 1.27 & 20.71 \\
\hline
\end{tabular}

Table 3.Effect of soil amendment with peat moss on rose wiltincidence (DI,\%), 90 days after planting during 2014 and 2015 seasons

\begin{tabular}{|c|c|c|c|c|c|c|c|c|}
\hline \multirow[t]{3}{*}{ Isolate } & \multicolumn{8}{|c|}{$\begin{array}{c}\text { Disease incidence of the treatments } \\
\text { (loamy Nile soil : peat moss (w/w) during }\end{array}$} \\
\hline & \multicolumn{4}{|c|}{2014} & \multicolumn{4}{|c|}{2015} \\
\hline & $1: 0$ & $1: 0.5$ & $1: 1$ & $1: 2$ & $1: 0$ & $1: 0.5$ & $1: 1$ & $1: 2$ \\
\hline $\mathrm{VD}_{1}$ & 100.0 & 83.3 & 66.7 & 41.7 & 100.0 & 75.0 & 58.3 & 50.0 \\
\hline $\mathrm{VD}_{2}$ & 91.7 & 75.0 & 66.7 & 41,7 & 91.7 & 75.0 & 50.0 & 41.7 \\
\hline $\mathrm{VD}_{8}$ & 91.7 & 75.0 & 41.7 & 33.3 & 91.7 & 66.7 & 50.0 & 33.3 \\
\hline Mean & 94.5 & 77.8 & 58.4 & 38.9 & 94.5 & 72.2 & 52.8 & 41.7 \\
\hline \multicolumn{5}{|c|}{$\begin{array}{l}\text { LSD 5\% for: } \\
\text { Isolates }(A)=0.48 \\
\text { Treatments }(B)=0.62 \\
(A x B) \quad=1.07\end{array}$} & \multicolumn{4}{|c|}{$\begin{array}{l}\text { LSD 5\% for: } \\
\text { Isolates }(A)=0.39 \\
\text { Treatments }(B)=0.74 \\
(A \times B)=1.28\end{array}$} \\
\hline
\end{tabular}


Table 4.Effect of soil amendment with peat moss on rose wilt severity (DS, \%), 90 days after planting during 2014 and 2015 seasons

\begin{tabular}{|c|c|c|c|c|c|c|c|c|}
\hline \multirow[t]{3}{*}{ Isolate } & \multicolumn{8}{|c|}{ Treatments (loamy Nile soil: peat moss (w/w) } \\
\hline & \multicolumn{4}{|c|}{ DS,\% during 2014 season } & \multicolumn{4}{|c|}{ DS, $\%$ during 2015 season } \\
\hline & $1: 0$ & $1: 0.5$ & $1: 1$ & $1: 2$ & $1: 0$ & $1: 0.5$ & $1: 1$ & $1: 2$ \\
\hline $\mathrm{VD}_{1}$ & 62.0 & 52.4 & 28.6 & 14.3 & 64.4 & 44.0 & 23.8 & 15.5 \\
\hline $\mathrm{VD}_{2}$ & 56.0 & 44.5 & 30.2 & 11.9 & 42.9 & 27.4 & 20.2 & 10.7 \\
\hline $\mathrm{VD}_{8}$ & 45.3 & 34.5 & 15.5 & 8.3 & 33.3 & 29.8 & 15.5 & 8.3 \\
\hline Mean & 54.4 & 43.8 & 24.8 & 11.5 & 46.9 & 33.7 & 19.8 & 11.5 \\
\hline \multicolumn{5}{|c|}{$\begin{array}{l}\text { LSD 5\% for: } \\
\text { Isolates }(A)=6.26 \\
\text { Treatments }(B)=10.33\end{array}$} & \multicolumn{4}{|c|}{$\begin{array}{l}\text { LSD 5\% for: } \\
\text { Isolates }(\mathrm{A})=9.62 \\
\text { Treatments }(\mathrm{B})=10.79 \\
(\mathrm{~A} \times \mathrm{B}) \quad=18.68\end{array}$} \\
\hline
\end{tabular}

3- Effect of compost on controlling Verticillium wilt of rose:

The effect of soil treatment with either Bio-Pianta or rice straw-based composts at concentration of 1:4 (compost/ soil, w/w) on Verticillium wiltof rose was studied during 2014 and 2015 seasons under greenhouse conditions. Results presented in Table (5) indicate that addition of either Bio-Pianta compost or rice straw compost to the soil before sowing significantly decreasedthe wilt of rose incidence and severity comparing with control, in both seasons. The percentages of reduction DI, $\%$ ranged between $60-88.9 \%$, and $44.4-88.9 \%$ at the two experimental seasons respectively, whereas DS\% values were reduced by $71-92 \%$ and $64.5-91.6 \%$. BioPianta compost caused higher reduction in both DI $\%$ and DS\% of rose wiltcomparing with rice straw.These results are in line with those obtained by Rose et al.(2003), who found that three composted media (greenhouse compost, windrow composted dairy solids and vermin-composted dairy solids) were added at seedling time, to a peat based medium inoculated with $F$. oxysporum f. sp. radicesсиситеrinum, reduced seedling mortality when measured after 37 days. They reported also that greenhouse compost was significantly more suppressive than the other two composts, and the suppression was partially eliminated by sterilization of the compost. 
Table 5. Effect of Bio-Pianta compost and rice straw- based compost on the incidence (DI, \%) and severity (DS, \%) of Verticilliumwilt of rose under greenhouse condition at growing seasons 2014 and 2015

\begin{tabular}{|c|c|c|c|c|c|c|c|c|c|c|}
\hline \multirow{2}{*}{$\begin{array}{c}\text { Isolate } \\
\text { No. }\end{array}$} & \multicolumn{5}{|c|}{ Disease incidence during 2014} & \multicolumn{5}{|c|}{ Disease severity during 20154} \\
\hline & $\begin{array}{c}\text { Bio- } \\
\text { Pianta }\end{array}$ & Red, $\%$ & $\begin{array}{l}\text { Rice } \\
\text { straw }\end{array}$ & Red, $\%$ & Cont. & $\begin{array}{c}\text { Bio- } \\
\text { Pianta }\end{array}$ & Red,\% & \begin{tabular}{|l|}
$\begin{array}{l}\text { Rice } \\
\text { straw }\end{array}$ \\
\end{tabular} & Red,\% & Cont. \\
\hline $\mathrm{VD}_{1}$ & 25.0 & $70.0^{(1)}$ & 33.3 & 60.0 & 83.3 & 11.9 & $80.8^{(1)}$ & 16.7 & 73.1 & 62.0 \\
\hline $\mathrm{VD}_{2}$ & 8.3 & 88.9 & 25.0 & 66.6 & 75.0 & 4.8 & 91.4 & 13.1 & 76.6 & 56.0 \\
\hline $\mathrm{VD}_{3}$ & 8.3 & 88.9 & 25.0 & 66.6 & 75.0 & 3.6 & 92.0 & 13.1 & 71.0 & 45.2 \\
\hline \multicolumn{6}{|c|}{$\begin{array}{l}\text { LSD 5\% for: } \\
\text { olates }(\mathrm{A}) \quad=0.5 \\
\text { Compost }(\mathrm{B})=1.2 \\
\quad \mathrm{~A} \times \mathrm{B}=0.8\end{array}$} & \multicolumn{5}{|c|}{$\begin{array}{l}\text { LSD 5\% for: } \\
\text { Isolate }(\mathrm{A})=11.4 \\
\text { Compost }(\mathrm{B})=22.7 \\
\mathrm{~A} \times \mathrm{B}=19.8\end{array}$} \\
\hline \multirow{2}{*}{$\begin{array}{c}\text { Isolate } \\
\text { No. }\end{array}$} & \multicolumn{5}{|c|}{ Disease incidence during 2015} & \multicolumn{5}{|c|}{ Disease severity during 2015} \\
\hline & $\begin{array}{c}\text { Bio- } \\
\text { Pianta }\end{array}$ & Red,\% & $\begin{array}{c}\text { Rice } \\
\text { straw }\end{array}$ & Red,\% & Cont. & $\begin{array}{c}\text { Bio- } \\
\text { Pianta }\end{array}$ & Red, $\%$ & \begin{tabular}{|l|} 
Rice \\
straw
\end{tabular} & Red, $\%$ & Cont. \\
\hline $\mathrm{VD}_{1}$ & 16.7 & 80.0 & 33.3 & 60.0 & 83.3 & 7.1 & 89.0 & 14.3 & 77.8 & 64.4 \\
\hline $\mathrm{VD}_{2}$ & 8.3 & 88.9 & 41.7 & 44.4 & 75.0 & 3.6 & 91.6 & 10.7 & 75.1 & 42.9 \\
\hline $\mathrm{VD}_{3}$ & 8.3 & 88.9 & 33.3 & 55.6 & 75.0 & 4.8 & 87.0 & 13.1 & 64.5 & 36.9 \\
\hline \multicolumn{6}{|c|}{$\begin{array}{cc}\text { LSD5\% for: } & \\
\text { Isolates }(\mathrm{A})= & 0.45 \\
\text { Compost }(\mathrm{B}) & =1.4 \\
\mathrm{~A} \times \mathrm{B} & =0.8\end{array}$} & \multicolumn{5}{|c|}{$\begin{array}{l}\text { LSD 5\% for : } \\
\text { Isolate }(\mathrm{A})=7.67 \\
\text { Compost }(\mathrm{B})=22.8 \\
\mathrm{~A} \times \mathrm{B} \quad=13.3\end{array}$} \\
\hline \multicolumn{11}{|c|}{ 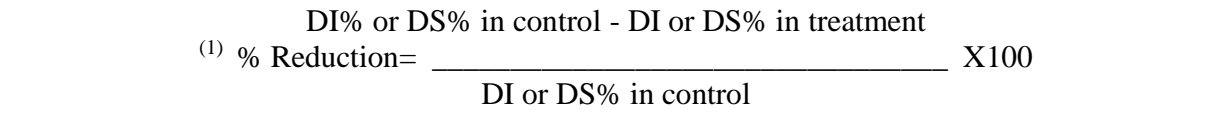 } \\
\hline
\end{tabular}

Composting the wastes of the farm animals and crops are known to improve the soil's structure, physical and chemical properties and nutritional status and microbiological activity (Garcia et al., 1992). Hoitink (1982) partially replaced composted tree bark instead of peat in pots media for producing ornamental plants. He found that this application added a new dimension to control, since composted tree bark is suppressive to many pathogens. Different mechanisms have been proposed to explain the suppressive capacity of organic amendments (Abawi and Widmer, 2000; Akhtar and Malik, 2000; Noble and Roberts, 2004 and Janivier et al., 2007).Among these mechanisms are enhanced activities of antagonistic 
microbes (Hoitink and Boehm, 1999), increased competition against pathogens (Lockwood, 1990), release of fungitoxic compounds (Smolinska, 2000) or induction of systemic resistance in host tissues.

\section{References}

Abawi, G.S. and Widmer, T.L. 2000. Impact of soil health management practices on soilborne pathogens, nematodes and root diseases of vegetable crops. Appl. Soil Ecol., 15:37-47.

Akhtar, M. and Malik, A. 2000. Roles of organic soil amendments and soil organisms in the biological control of plant-parasitic nematodes: a review. Bioresource Technol., 74: 35-47.

Aly, A.Z.;Tohamy, M.R.A. and Attia, M.M. 2002. Grapevine twigs tip die-back disease in Egypt. Egypt. J. Phytopathol., 30(1): 45-56.

Armanious,HanaaA.H.2016.Verticillium wilt on rose plants in Minia Governorate and its control. Egypt. J. Phytopathol., 44(2): 133 -154.

Bejarano-Alcázar, J.;Blanco-López, M.A.; Melero-Vara, J.M. and JiménezDíaz, R.M. 1996. Etiology, importance, and distribution of Verticillium of cotton in Southern Spain. Plant Dis. 80:1233-1238.

Borrero, C.; Trillas, M.I.; Ordovas, J.; Tello, J.C. and Avilés, M. 2004. Predictive factors for the suppression of Fusarium wilt of tomato in plant growth media. Phytopathology,94: 1094-1101.

Cotxarrera, L.; Trillas-Gay, M.I.; Steinberg, C. and Alabouvette, C. 2002.Use of sewage sludge compost and Trichoderma asperellum isolates to suppress Fusarium wilt of tomato. Soil Biol. Biochem., 34: 467-476.

Garcia, C.; Hernandez, T. and Cosia,F. 1992. Variation in some chemical parameters and organic matter in soils regenerated by the addition of municipal solid waste. Environ. Manag., 16:763-768.

Golueke, C.G. 1972. Composting, a Study of the Process and its Principles. Rodale Press Inc., Book Div., Emmous, PA, pp:1-110.

Hammett, K.R.W. 1971. Symptom differences between rose wilt virus and Verticillium wilt of roses. Plant Dis. Report, 55:916-920.

Hoitink, H.A.J. 1982. Composted bark, a light weight growth medium with fungicidal properties. J. Amer. Rhododen. Soc., 36(2): 1-5.

Hoitink, H.A.J. and Boehm, M.J. 1999. Biocontrol within the context of soil microbial communities: a substrate-dependent phenomenon. Ann. Rev. Phytopathol., 24: 93-114. 
Hoitink, H.A.J. and Fahy, P.C. 1986. Basis for the control of soil borne plant pathogens with composts. Annu. Rev. Phytopathol., 24:93-114.

Hoitink, H.A.J.;Schmitthener, A.F. and Herr, L.J. 1975. Composted bark for control of root rot in ornamentals. J. Arboric Ohio Rep., 60: 25-26.

Horst,K.R.1983. Compendium of Rose Diseases. The American Phytopathological Society. St. Paul, Minnesota. USA.,50 p.

Janvier, C.; Villeneuve, F.; Alabouvette, C.; Edel-Hermann, V.; Mateille, T. and Steinberg, C. 2007. Soil health through soil disease suppression: Which strategy from descriptors to indicators.Soil Biol. Biochem.,39 (1): 1-23.

Larkin, R.P. 2008. Relative effects of biological amendments and crop rotations on soil microbial communities and soilborne diseases of potato. Soil Biol. and Biochemis., 40 (6): 1341 - 1351.

Li, L.; Kageyama, K.; Kinoshita, N. and Yu, W. 2007. Development of bioassay for screening of resistant roses against root rot disease caused by Pythium helicoides Drechsler. Engei Gakkai Zasshi, 76(1): 79-84.

Litterick, A.M.; Harrier, L.; Wallace, P.; Watson, C.A. and Wood, M. 2004. The role of uncomposted materials, composts, manures, and compost extracts in reducing pest and disease incidence and severity in sustainable temperate agricultural and horticultural crop production: A review. Crit. Rev. Plant Sci., 23(6): 453-479.

Lockwood, J.L. 1990. Relation of energy stress to behaviour of soilborne plant pathogens and to disease development. In: Biological Control of Soilborne Plant Pathogens,Hornby, D. (ed.), CAB International, Wallingford, UK, pp. 197-214.

Noble, R. and Roberts, S.J. 2004. Eradication of plant pathogens and nematodes during composting: a review. Plant Pathol., 53(5): 548-568.

Pacholczak, A. and Szydlo, W. 2008. Effect of ammonium zinc acetate on rooting of stem cuttings of Physocarpusopulifolius.Ann. of Warsow Univ. of Life Sci-SGGW, Horticulture and Landscape Architecture, 29: 59-64.

Pane, C.; Spaccini, R.; Piccolo, A.; Scala, F. and Bonanomi, G. 2011. Compost amendments enhance peat suppressiveness to Pythium ultimum, Rhizoctoniasolani andSclerotinia minor. Biol. Cont., 56:115-124.

Rag, H. and Kapoor, I.J. 1997. Possible management of Fusarium wilt of tomato by soil amendments with composts. Indian Phytopath., 50(3): 387- 395.

Rose, S., Parker, M. and Punja, Z.K. 2003. Efficacy of biological and chemical treatments for control of Fusarium root and stem rot on greenhouse cucumber.Plant Dis., 87(12): 1462-1470. 
Smolinska, U. 2000. Survival of Sclerotium cepivorm sclerotia and Fusarium oxysporum chlamydospores in soil amended with cruciferous residues.J. Phytopathol., 148(6): 343-349.

Snedecor, G.W. and Cochran, W.G.1980. Statistical Analysis Methods $7^{\text {th }}$ ed. Iowa State Univ. PressAmes, Iowa, USA.215- 237. 


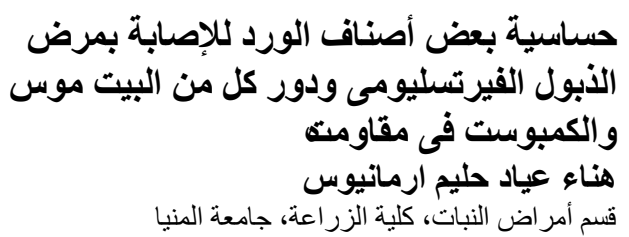

Rosa gallica var. اختبرت ست أنو اع وأصناف من الورد، هيى

Aegyptiaca, Rosa hybridavar. Hamoschush, Rosa. hybrid var. Queen, Rosa hybrida var. Yellow, Rosa hybridavar. White and Rosa canina,

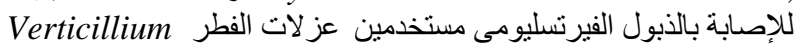
dahliae

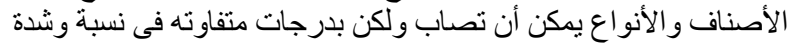
الإصابة. وقد سبيت العزلتان رقمى الإن

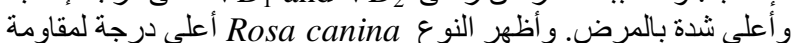

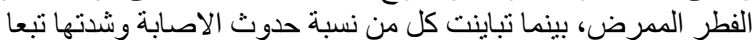
لأصناف الورد المختلفة. أدى إضافة البيت موس م

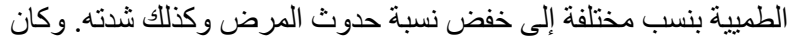
انخفاض نسبة حدوث الإصابة وشدتها متناسبا طرديا مع زيادة الفر معدل

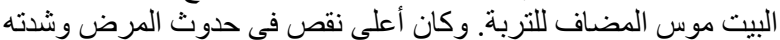

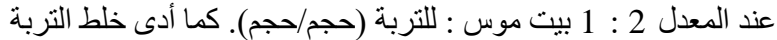
بكمبوست مصنوع من أى من سيقان فول الصويا (بيو بيانتا) أوقش الأرز

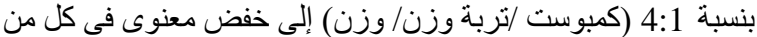

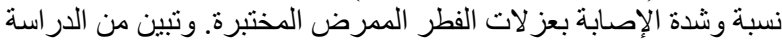

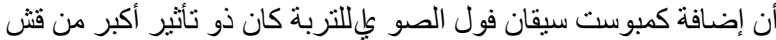
الأرز في خفض شدة ونسبة حدوث الذبول الفيرتسليو مي فى الونى الورد. 